Original Research

\title{
Increasing Area of Deciduous Forest Communities (Querco-Fagetea Class) as an Unintended Effect of Regular Forestry Management - a Study from Central Europe
}

\author{
Krzysztof Świerkosz*, Kamila Reczyńska, Iwona Kuras \\ Museum of Natural History, Wrocław University, Sienkiewicza 21, PL-50-335, Wrocław, Poland
}

Received: 13 June 2016

Accepted: 18 August 2016

\begin{abstract}
Our paper presents a comparison of historical data concerning the distribution of forest communities in the Sowie Mountains in southwestern Poland in 1968-71 with material collected by the authors between 2009 and 2013. The analyses were performed using geographic information system software. The archival vegetation maps were digitized, and the layer of the current distribution of forest communities was applied afterward. Archival data indicated that, in the study area, spruce monocultures of anthropogenic character predominated, occupying $90 \%$ of forest area. The obtained results suggest that regular forest management conducted within the study area has surprisingly contributed to an increase in the area of forest communities of the Querco-Fagetea class from 766 to 1,579 ha (more than 100\%) over the last 45 years. The largest rise in the area of studied communities was observed on meso-oligotrophic habitats, and was reflected in the increase of the area of acidophilous beech forests, representing Luzulo luzuloidis-Fagetum association (habitat 9110 protected in the European Union), from 168 ha to1,064 ha. There was a minor decrease in the area of submontane riparian forests Carici remotae-Fraxinetum (habitat 91E0); the area of mesotrophic beech forests Galio odorati-Fagetum (habitat 9130) seems to be stable. Approximately $72 \%$ of deciduous forests in the study area have retained their spatial cover for 45 years.

The newly created forest communities are deprived of a number of essential elements of the structure, primarily dead wood, including lying trunks and trees. The lack of these features does not allow us to assess the status of these ecosystems as entirely satisfactory. However, the possibility of converting Picea abies monocultures in deciduous forests of the Querco-Fagetea class under regular forest management should be considered beneficial to the conservation status of forest ecosystems of mountain areas of Central Europe.
\end{abstract}

Keywords: sustainable forestry management, forest regeneration, vegetation history, ecosystem restoration, Natura 2000 habitats, Poland

*e-mail: krzysztof.swierkosz@life.pl 


\section{Introduction}

Almost all Europe's native forests have been cleared or logged at various intensities for centuries [1-2], and now they seem to be a man-made ecosystem rather than natural [3]. The changes in the distribution of natural mountain forests in Central Europe were also caused by the excessive use of forest resources, although at higher altitudes it started later than in the lowlands, namely between the $14^{\text {th }}$ and $18^{\text {th }}$ centuries [4-5]. In the Sudetes, which constitutes Polish and Czech parts of the Hercynian Arc, primeval beech and beech-fir-spruce forests were exploited with particular intensity, which led to almost total deforestation in some mountain ranges [6-7]. This process peaked in the first half of the $19^{\text {th }}$ century, resulting in soil erosion and deterioration of living conditions in local communities. Efforts to restore forest cover were made in the latter half of the $19^{\text {th }}$ century [6-7], mainly through the planting of Norway spruce Picea abies, which led to the creation of extensive monocultures of this species. Similar restoration measures were also recorded in other mountain ranges of Central Europe [8]. Anthropogenic, monotonous, and poor-in-species spruce forests are still the predominant forest community in the Sudetes, both in Poland and the Czech Republic, occupying a large area, even within national parks [5, 9-10]. In 2008 Norway spruce was a dominant species on the $72 \%$ of the forest area in the Polish part of the Sudetes [11].

Currently, the gradual conversion of spruce monocultures toward forest communities of a close to natural character, is a common goal of forestry and nature conservation in most of the mountain ranges of Central Europe. This issue has been repeatedly addressed in numerous studies [e.g., 12-19], as well as in monographs and during conferences devoted exclusively to this topic [e.g., 8, 20].

Presently, the restoration of these monocultures in the Sudetes is motivated not only by the ecological features of renewal ecosystems, but mostly by attention to the health condition and diversity of the tree stands after dramatic damage caused by air pollution and catastrophic events [11]. This process relies mainly on plantings or restocking of Fagus syvatica beech or Quercus robur, Q. petraea oaks and, to a lesser extent, Abies alba silver fir, Acer pseudoplatanus sycamore, Fraxinus excelsior mountain ash, and Tilia cordata small-leaved lime. However, it is worth mentioning that this approach may contribute to the formation of forest communities that are similar in tree and herb layer species composition to the communities protected in the European Union as part of Annex I of Directive 92/43/EEC, even if they are semi-natural in character [21].

So far, the analyses of changes in forest area in the Sudetes have focused only on changes in total cover of the forest stands. A significant increase in the acreage of forests has been noted over the last 100 years $[5,7$, 22]. However, present attempts to reconstruct these processes focused on neither species composition nor the syntaxonomical position of phytocoenoses. Therefore, they are more quantitative than qualitative in character due to the lack of archival materials that would make such comparisons possible. The exception in Poland is the Sowie Mountains (Sudetes, southwestern Poland) for which a map of vegetation illustrating the distribution of forest communities was prepared in 1968-71 [23]. During that time, most of the studied area (about 90\%) was covered by a Norway spruce monoculture with only single patches of deciduous forest preserved among them. Since then, forests in the Sowies have been under regular management, which allows us to evaluate its impact on the distribution and area of forest communities within this particular mountain range. Although it is commonly known that silviculture plays an essential role in shaping forest communities in Europe, in literature sources there is almost no information specifying its qualitative effect, particularly in reference to the regeneration of communities whose tree and herb species composition resemble those typical of natural forests. The material collected in the 1960s in the Sowies gives us a unique opportunity to use and test the changes in the forest communities under the influence of human activity.

The purpose of this study is to determine changes in the area and continuity of distribution of regularly managed deciduous forests recorded in the late 1960s in the Sowies, in comparison with their state identified during research conducted in 2009-13. This enables us to answer the following questions:

1. To what extent has forest management in the study area contributed to the quantitative and qualitative changes in forest communities over the last 40 years?

2. Should the regeneration of spruce monocultures in Central Europe be based on conservation measures specially created for this purpose, or may it take place under standard and planned forest management?

\section{Experimental Procedure}

\section{Study Area}

Research covered the forest area of the Sowie Mountains Landscape Park (Fig. 1) with an acreage of 8,140 ha, of which 1,316.9 ha were located in the western part (Włodarz Massif) and 6,823.1 ha in the eastern part (the main ridge of the Sowies). Both parts are isolated by the deep, deforested, and intensively developed Walimka River Valley. The highest peak in the western part is Włodarz (811 $\mathrm{m}$ a.s.1.) and in the eastern part Wielka Sowa (1,015 $\mathrm{m}$ a.s.1.). The study area is part of the Góry Sowie Gneiss Massif, which is considered a separate fragment of the Bohemian Massif [24]. It is made of several types of gneisses deriving from the metamorphism of greywacke and pelites in the period between 380 and 370 million years ago. They are accompanied by granulites, amphibolites, and occasionally by ultrabasites [25]. The Sowies are located within two forest zones: foothills (up to approx. $500 \mathrm{~m}$ a.s.l.) and lower subalpine forest zone. The 


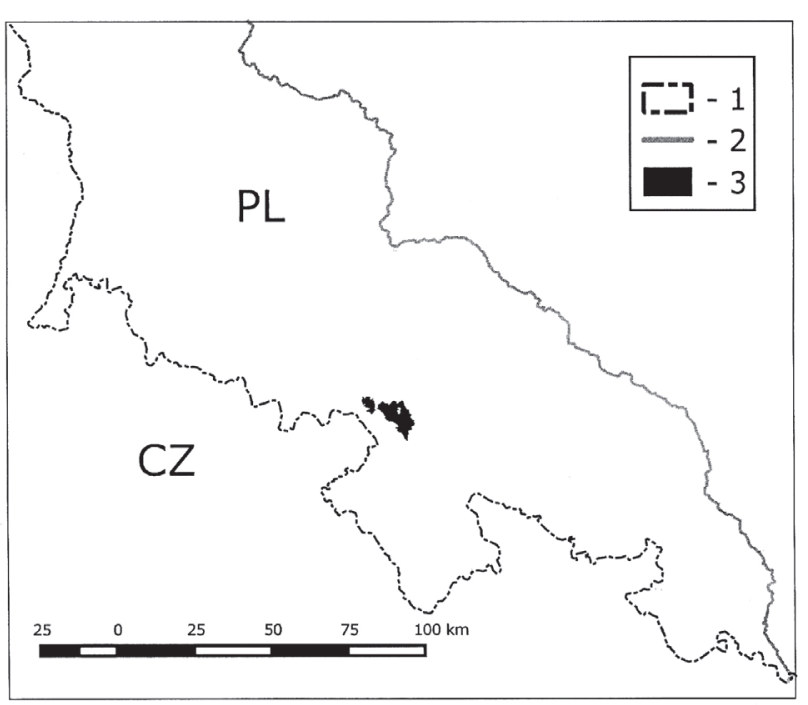

Fig. 1. The location of the study area. Explanation: 1 - state boundaries ( $\mathrm{PL}$ - Poland, CZ - Czech Republic), 2 - main rivers, 3 - area of investigation (Sowie Mountains Landscape Park).

upper parts of Wielka Sowa Mountain above 1,000 m a.s.l. were sometimes considered to be a fragment of the upper mountain forest zone [23]. However, in light of recent studies that claim does not seem to be justified [26]. The average annual temperature varies between 3.5 and $5.5^{\circ} \mathrm{C}$, while the vegetation period lasts from 165 to 180 days [27]. The forest cover within the landscape park is $94 \%$. The study area is a part of Natura 2000 site PLH020071 Ostoja Nietoperzy Gór Sowich [28].

The study area is managed by four separate bodies of the Polish Forestry Administration (Jugów, Wałbrzych, Świdnica, and Bardo) belonging the Regional Directorate of State Forests in Wrocław. From the beginning of the $20^{\text {th }}$ century even aged forest management was the main type of forestry in this region and it continued after World War II - in particular within the spruce monocultures. In parallel, especially since 1990, uneven aged management (e.g., shelterwood, seed-tree regeneration, patch cuts) was introduced. However, this process occurs gradually, due to the large areas of even aged monocultures dating back to the turn of the $19^{\text {th }}$ and $20^{\text {th }}$ centuries [29].

\section{Methods}

The map of vegetation at a scale of about 1:75,000 made by Pender [23] was georeferenced based on topographical maps that were available at the beginning of the 1970s, according to the 1992 National Geodetic Coordinate System. The intersections of the main roads in the vicinity of the Sowies were established as the reference points. A linear transformation was used, and the average error of fitting the raster was 13 pixels. The polygons representing the patches of forest communities were digitized using the on-screen method, and subsequently additional calibration of the polygons' location was performed based on stream valleys as a fixed element of the terrain.
The current distribution of forest communities was studied in 2009-13 by fieldwork, which was preceded by the analysis of aerial photographs as well as data concerning the distribution of the main tree species dominating the stands provided by the forest service. The documentation of studied communities is represented by 125 relevés, which were transferred to the Polish Vegetation Database [GIVD ID: stored in a TURBOVEG database [30] and EUPL-001 Database; [31]. Phytosociological relevés were collected according to the Braun-Blanquet approach [32] within an area of $200 \mathrm{~m}^{2}$, including three layers of stand, and shrub, herb, and moss layers. The juvenile stages of forest communities with a stand younger than 30 years as well as patches with a share of coniferous species higher than $50 \%$ were excluded from the mapping. Obtained results were digitized as separate layers in ESRI format.

Afterward, the area of particular forest communities recorded in 1968-71 was compared with the results of research conducted between 2009 and 2013. In order to collate the stability of location of phytocoenoses in time and space, an additional buffer (with a radius of $100 \mathrm{~m}$ ) was established for each patch of community originating from the archival data. The size of the buffer corresponded to the maximum error of forest communities shifting in relation to the streams on the topographical map. The area shared by forest communities of the QuercoFagetea class in 1968-71 and 2009-13 was calculated for the entire buffer. All analyses were performed using the QGIS 2.8.3 software with vector analysis package fTools 0.6.2. The nomenclature of forest communities follows Matuszkiewicz [33].

\section{Results}

The forest communities of Querco-Fagetea were occupied in 1968-71, an area of 776.6 ha, of which 448.2 ha were identified as Galio odorati-Fagetum (as Dentario enneaphyllidis-Fagetum), 168.3 ha as Luzulo luzuloidisFagetum, 5.2 ha as Fraxino-Alnetum, 142.2 ha as Carici remotae-Fraxinetum, and 2.6 ha as Galio sylvaticiCarpinetum (Figs 2a, 3a).

Between 2009 and 2013 the communities included in Querco-Fagetea occurred over a total area of 1,579.3 ha, of which 1,064.3 ha were covered by phytocoenoses of Luzulo luzuloidis-Fagetum, 432.2 ha by Galio odoratiFagetum and 82.1 ha by submontane riparian forests representing Carici remotae-Fraxinetum. The presence of Fraxino-Alnetum and Galio sylvatici-Carpinetum recorded in previous locations was not confirmed (Figs $2 b, 3 b)$.

The total percentage of deciduous forests of Querco-Fagetea has increased from $9.4 \%$ to $19.4 \%$ in the whole study area. The forest communities documented in 1968-71 and then in 2009-13 shared an area of 554 ha (including a buffer of $100 \mathrm{~m}$ ), meaning that approximately $72 \%$ of old vegetation patches were preserved at the same location and at least $28 \%$ developed in an area previously occupied by spruce monocultures, probably with the 
a)

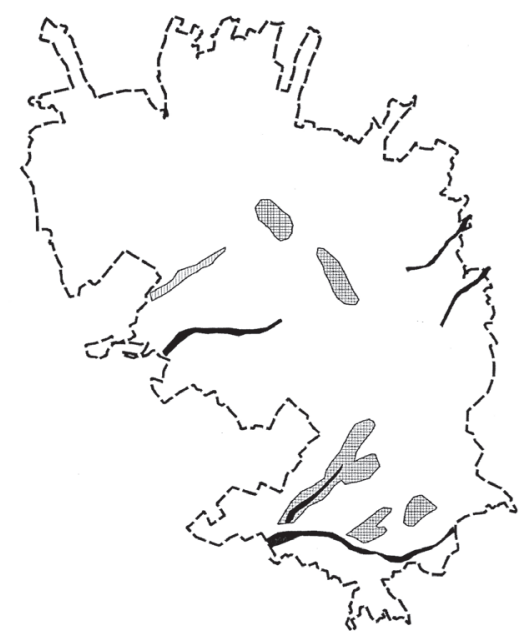

-1
-3
-3

$500 \quad 0 \quad 500 \quad 10001500 \quad 2000 \mathrm{~m}$

b)
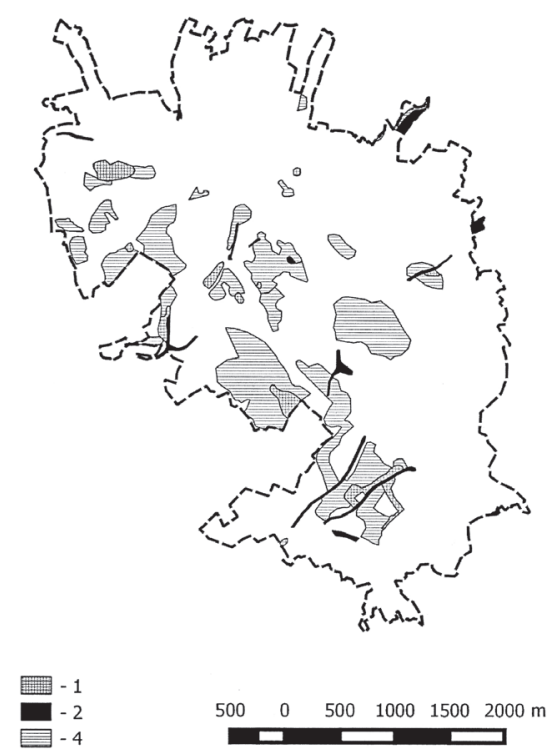

Fig. 2. Distribution of forest communities of the Querco-Fagetea class in the western part (Włodarz Massif) of the Sowie Mountains Landscape Park (Poland, Central Europe): a) years 1968-71, b) years 2009-13. Explanation: 1 - Galio odorati-Fagetum, 2 - Carici remotae-Fraxinetum, 3 - Fraxino-Alnetum, 4 - Luzulo luzuloidis-Fagetum.

presence of young deciduous trees growing in lower layers.

In terms of the main features of floristic structure, we noted a clear impoverishment of phytocoenoses. In the natural communities of the lower subalpine forest zone in 1968-72, any synanthropic species were recorded. They only occurred sporadically in foothills below $500 \mathrm{~m}$ a.s.1. [23]. In relevés collected between 2009 and 2014, neophytes such as Impatiens parviflora or Digitalis purpurea were recorded above $800 \mathrm{~m}$ a.s.l., even in the Bukowa Kalenica Nature Reserve. Also, nitrophilous species such as Stellaria media, Geranium robertianum, and Geum urbanum observed by Pender [23] occasionally become much more frequent. The disappearance of species typical of eutrophic deciduous forests of the lower subalpine zone, such as Polystichum braunii, Polystichum aculeatum, Lunaria rediviva, or Dentaria enneaphyllos, was observed as well.

\section{Discussion}

The presented results, despite the possibility of errors associated with comparing archival and contemporary data, clearly indicate that the area of deciduous forests in the Sowie Mountains (protected under the Annex 1 of Directive 92/43/EEC) changed significantly during the studied period of time. These changes are of both quantitative and qualitative character. The total area of deciduous forests in the study area has increased from 766 to 1,579 ha over the last 45 years.

This rise was mainly recorded in meso-oligotrophic habitats and was reflected in the increase in the area of acidophilous beech forests of the Luzulo luzuloidis-
Fagetum (from 168 ha to 1,064 ha). This process was mainly observed in the western part of the Sowies, where the above-mentioned phytocoenoses were not found at all between 1968 and 1971, but currently occupy almost 230 ha (Fig. 2). The area of mesotrophic beech forests turned out to be almost stable, while a decrease in the area of riparian forests represented by Carici remotae-Fraxinetum was likely caused by the imprecise presentation of their cover on the archival map where they were marked as lines, with a width of 30 to even $90 \mathrm{~m}$ - far exceeding the real range of these forests.

Because in the current analysis only tree stands older than 30 years were included, this means that the process of regeneration of communities had to begin as early as the time when the previous research [23] was conducted. Young beech stands and their regenerative stages within spruce monocultures were probably not treated as beech phytocoenoses by Pender [23], and therefore she did not record them on the map of forest communities. However, their current distribution and occupied area clearly indicate their former existence.

Undoubtedly, a significant increase of Luzulo luzuloidis-Fagetum forest area is a direct effect of the impact of forestry measures contributing to the rise in the share of beech and the progressive restoration of quantitative relationships within forest stands. The planned standard measures within forest management in the landscape park of the Sowies were obviously modified as a result of random events. These included the weakening of forest stands due to excessive acid rain, which accelerated the dieback of spruce stands in many mountain ranges of the Sudetes Mountains [34], outbreaks of pests [34-35], and natural disasters - especially heavy storms, which regularly plagued the Sudetes in the postwar years [11]. Special recommen- 
a)

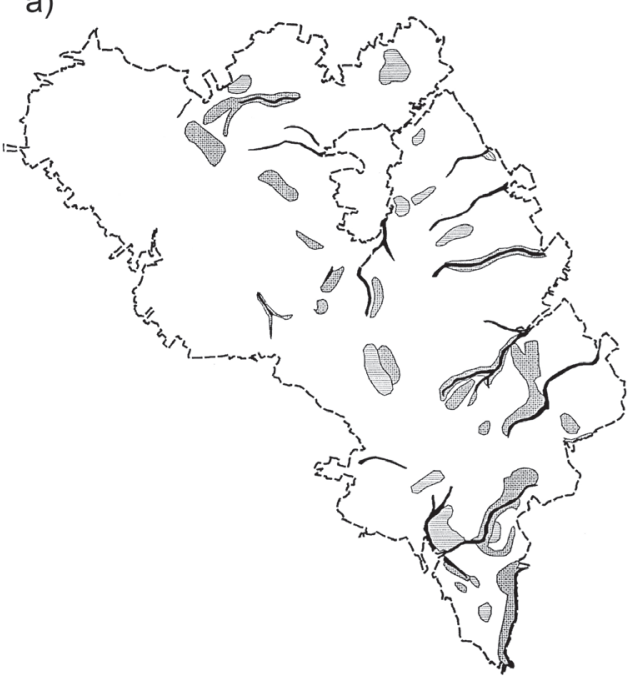

b)

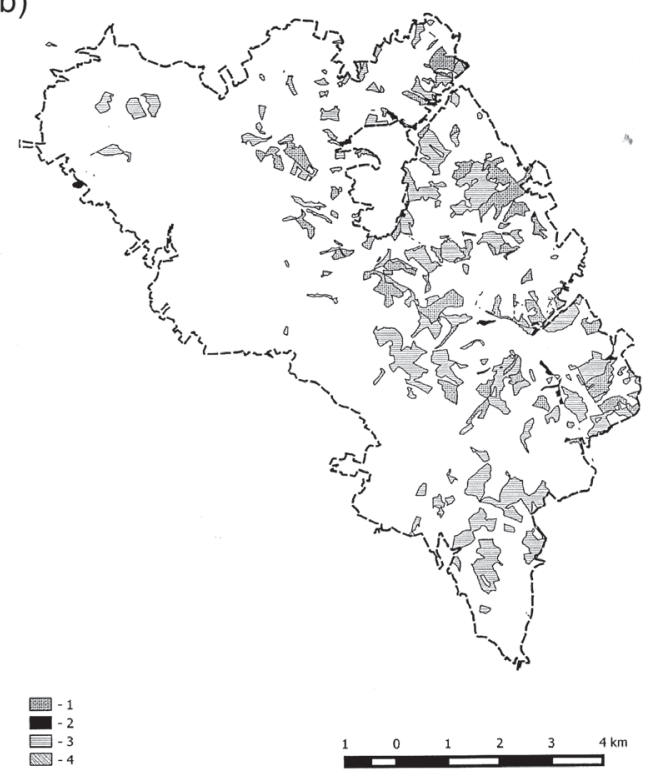

Fig. 3. Distribution of forest communities of the Querco-Fagetea class in the eastern part (main ridge of the Sowie Mts) of the Sowie Mountains Landscape Park (Poland, Central Europe): a) years 1968-71, b) years 2009-13.

Explanation: 1 - Galio odorati-Fagetum, 2-Carici remotae-Fraxinetum, 3-Luzulo luzuloidis-Fagetum, 4 - Galio sylvatici-Carpinetum.

dations for forest management in the landscape park (including the introduction of large-scale uneven aged type of management with long renewal time) were formulated for the first time in 2009-11, during the preparation of both management plans for forestry operational units (Wałbrzych and Bardo 2009, Świdnica and Jugów 2011) and guidelines for the management plan for the Sowie Mountains Landscape Park in 2010.

The obtained results show the role of forestry in regeneration of communities typical of the lower forest zone in the Sudetes, and thus they suggest the occurrence of a similar process in the other mountain ranges of Central Europe. They also indicate that the use of a combination of standard management measures and natural processes can significantly stimulate the process of forest habitat regeneration [36-38]. The most commonly used methods are renewal under the coniferous shelterwood [15] or the creation of gaps with natural or artificial restocking [39]. It is worth mentioning that sometimes the removal of some planted species enables spontaneous growth of other tree species (including beech) and causes an increase in biodiversity of both herb layer and undergrowth [4041]. Further modification of the management strategy may allow for other regenerative changes, especially in terms of diversity associated with dead wood, which is one of the key factors determining the ecological value of forest ecosystems [42-44]. Of course a significant increase in the proportion of dead wood in beech forests younger than 200 years [45] would require additional measures of forest management consisting of deliberate cutting and leaving of old trees because within man-made and semi-natural forests this process proceeds very slowly [46].

Presented results also revealed that the general increase in the area of forest communities is not directly reflected in its ecological quality. The disappearance of the small patches of phytocoenoses of Galio-Carpinetum and Fraxino-Alnetum, without any doubt, had anthropogenic causes. In the place where oak-hornbeam forests were recorded, presently Larix decidua monoculture occurs, while the floodplain forests, which previously occupied the unnamed stream valley near the city of Jedlina Zdrój, were replaced by fish ponds.

According to research conducted between 2013 and 2014 as part of the monitoring of natural habitats [47], the conservation status of forest communities in the Sowies was assessed as unfavorable (U1) with reference to habitat 9110 (Luzulo luzuloidis-Fagetum), and as bad (U2) in the case of 9130 (Galio odorati-Fagetum) and 91E0 (Carici remotae-Fraxinetum) habitats. The main causes of such an assessment were the very small proportion of dead wood (less than $5 \mathrm{~m}^{3} /$ ha) and large-sized trunks (less than $3 /$ ha), juvenilization of forest stands, and a high share of neophytes (mainly Impatiens parviflora). The problem of low biodiversity of beech forests as a consequence of intensive forest management in Europe (even within Natura 2000 sites) was commonly reported [2, 37, 43, 4849]. The main causes of this situation (also applicable in the study area) were the removal of dead wood and the lack of trees older than 180-200 years old. Meanwhile, in many strictly protected areas a decrease in diversity of species and productivity of vascular plants was observed. The main reasons for this were the excessive density of canopy and shading of the herb layer. Therefore, in such cases, the use of moderate measures may prevent negative changes $[2,38,50]$. Hence, it is essential to develop appropriate methods of management of forest communities listed in Annex 1 of Directive 92/43/EEC at the national level, which may have a decisive influence on their ecological 
status [44] and help raise awareness of protection of forest communities among stakeholders [51].

\section{Conclusions}

Our study suggests that it is possible to transform the nineteenth century spruce monocultures in Central Europe in the deciduous forest ecosystems of the QuercoFagetea class, in the framework of traditional forestry, whose main purpose is wood production. Of course, such unwittingly reconstructed ecosystems, especially beech forests, cannot reach favourable conservation status while this type of management is maintained consistently within them. However, further modification of measures can contribute to their improvement. Thus, traditional forest management, at least in the initial but possibly also in the mature stands, can play an important and positive role in the regeneration of forests protected under Directive 92/43/EEC, and should be considered beneficial to both the protection and conservation status of forest ecosystems of mountain areas of Central Europe.

\section{Acknowledgements}

We are grateful to Amanda Anthony, who kindly corrected our English, and for the anonymous reviewer who contributed remarkably to the improvement of this paper.

We also would like to thank the Bureau of Forest Management and Geodesy in Brzeg for its help in obtaining and interpreting of forest inventory data.

\section{References}

1. KAPLAN J.O., KRUMHARDT K.M., ZIMMERMANN N. The prehistoric and preindustrial deforestation of Europe. Quaternary Sci. Rev. 28 (27-28), 3016, 2009

2. PAILLET Y., BERGÈS L., HJÄLTÉN J., ÓDOR P., AVON C., BERNHARDT-RÖMERMANN M., BIJLSMA R.J., DE BRUYN L., FUHR M., GRANDIN U., KANKA R., LUNDIN L., LUQUE S., MAGURA T., MATESANZ S., MÉSZÁROS I., SEBASTIÀ M.T., SCHMIDT W., STANDOVÁR T., TÓTHMÉRÉSZ B., UOTILA A., VALLADARES F., VELLAK K., VIRTANEN R. Biodiversity differences between managed and unmanaged forests: metaanalysis of species richness in Europe. Conserv. Biol. 24 (1), 101, 2010.

3. NOBLE I.R, DIRZO R. Forests as Human-Dominated Ecosystems. Science 277, 522, 1997.

4. KORTA W. Economical life in Silesia during feudal period 44, 11, 1986

5. SZYMURA T.H., DUNAJSKI A., RUCZAKOWSKA A.M. Changes of forest cover in the Karkonosze National Park area in 1747-1977 period. Opera Corcontica 47 Suppl 1, 159, 2010.

6. LATOCHA A., MIGOŃ P. Geomorphology of medium-high mountains under changing human impact, from managed slopes to nature restoration: a study from the Sudetes, SW Poland. Earth Surf. Proc. Land. 31 (13), 1657, 2006.
7. LATOCHA A. Land-use changes and longer-term humanenvironment interactions in a mountain region (Sudetes Mountains, Poland). Geomorphology 108 (1-2), 48, 2009.

8. KLIMO E., HAAGER H., KULHAVÝ J. Spruce monocultures in Central Europe - problems and prospects. Eur. Forest Inst. Proc. 33, 208, 2000.

9. BORATYŃSKI A. Chorological analysis of woody flora of the Western Sudety Mts. Polska Akademia Nauk Instytut Dendrologiczny, Kórnik; 1991.

10. HÉDL R., PETŘÍK P., BOUBLÍK K. Long-term patterns in soil acidification due to pollution in forests of the Eastern Sudetes Mountains. Environ. Pollut. A 159 (10), 2586, 2011.

11. PAWLIK $Ł$. Forest damage in the Sudety Mts. caused by the Kyrill storm (18-19.01.2007) - historic and regional implications. Przegląd Geograficzny 84, 53, 2012.

12. FANTA J. Rehabilitating degraded forests in Central Europe into self-sustaining forest ecosystems. Ecol. Eng. 8 (4), 289, 1997.

13. KAZDA M., PICHLER M. Priority assessment for conversion of Norway spruce forests through introduction of broadleaf species. Forest Ecol. Manag. 102 (2-3), 245, 1998.

14. KNOKE T., AMMER C., STIMM B., MOSANDL E. Admixing broadleaved to coniferous tree species: a review on yield, ecological stability and economics. Eur. J. Forest Res. 127 (2), 89, 2008.

15. LÖF M., BERGQUIST J., BRUNET J., KARLSSON M., WELANDER N.T. Conversion of Norway spruce stands to broadleaved woodland - regeneration systems, fencing and performance of planted seedlings. Ecol. Bull. 53, 165, 2010.

16. FELTON A., LINDBLADH M., BRUNET J., FRITZ Ö. Replacing coniferous monocultures with mixed-species production stands: An assessment of the potential benefits for forest biodiversity in northern Europe. Forest. Ecol. Manag. 260 (6), 939, 2010.

17. WAGNER S., COLLET C., MADSEND P., NAKASHIZUKAE T., NYLANDF R.D., SAGHEBTALEBIG K. Beech regeneration research: From ecological to silvicultural aspects. Forest. Ecol. Manag. 259 (11), 2172, 2010.

18. AMBROŻY S., KOSIBOWICZ M. Damage to regeneration in the area after large-scale decline of Norway spruce Picea abies (L.) H. Karst. stands in the mountains. Folia For Pol Ser A 54 (1), 3, 2012.

19. HANSEN J., SPIECKER H. Conversion of Norway spruce (Picea abies [L.] Karts.) forests in Europe. In: Stanturf JA. (ed), Restoration of boreal and temperate forests, second edition. CRC Press; 355, 2015.

20. SPIECKER H., HANSEN J., KLIMO E., SKOVSGAARD J.P., STERBA H., VON TEUFFEL K. (eds), Norway spruce conversion options and consequences. European Forest Institute Research Reports, Leiden, Boston, Köln; 2004.

21. KETTUNEN M., TERRY A., TUCKER G., JONES A. Guidance on the maintenance of landscape features of major importance for wild flora and fauna - Guidance on the implementation of Article 3 of the Birds Directive (79/409/ EEC) and Article 10 of the Habitats Directive (92/43/EEC). Institute for European Environmental Policy (IEEP), Brussels; 2007.

22. JAWOREK J., FILIPAK M., NAPIERALA-FILIPIAK A. Changes in the area covered by woody plants communities in the Karpnicki Potok valley as an example of changes in forest area in lower parts of the Sudety Mountains. Sylwan 158 (9), 704, 2014.

23. PENDER K. Zbiorowiska leśne Gór Sowich. Acta Univ. Wrat. 269 Prace Bot. 20, 3, 1975. 
24. OBERC J. Polish geological structure. Vol 4. Tectonics Vol. 2: Sudetes and adjanced areas. Wydawnictwo Geologiczne, Warszawa; 1972.

25. ŻELAŹNIEWICZ A., ALEKSANDROWSKI P. Regionalizacja tektoniczna Polski - Polska południowozachodnia. Przegląd Geologiczny 56 (10), 904, 2008.

26. RECZYŃSKA K., ŚWIERKOSZ K. Remarks about the diversity of mountain Norway spruce forest in the Sudetes with particular reference to the Szczeliniec Massif (Stołowe Mts, Poland). In: Migoń P, Kasprzak M (eds.), Sandstone Landscapes. Diversity, Ecology and Conservation. Institute of Geography and Regional Development, Wrocław University, Wrocław; 153, 2013.

27. GŁOWICKI G., OTOP I., URBAN G., TOMCZYŃSKI K. Climate. In: Ecophysiograpic study for the Lover Silesian Voivodship. Wojewódzkie Biuro Urbanistyczne, Wrocław; 53, 2005.

28. ŚWIERKOSZ K., SZKUDLAREK R., GOTTFRIED I., GOTTFRIED T., FURMANKIEWICZ J., ZAJĄC T. Ostoja Nietoperzy Gór Sowich. In: Świerkosz K, Liberacka H, Łysiak M, Zając K (eds.), Obszary Natura 2000 na Dolnym Śląsku. Regionalna Dyrekcja Ochrony Środowiska, Wrocław; 208, 2012.

29. MEDERSKI P.S., JAKUBOWSKI M., KARASZEWSKI $Z$. The Polish landscape changing due to forest policy and forest management. iForest 2, 140, 2009.

30. HENNEKENS S.M., SCHAMINÉ, J.H.J. Turboveg, a comprehensive database management system for vegetation data. J. Veg. Sci. 12 (4), 589, 2001.

31. KĄCKI Z., ŚLIWIŃSKI M. The Polish Vegetation Database: structure, resources and development. Acta Soc. Bot. Pol. 81 (2), 75, 2012.

32. MUELLER-DOMBOIS D., ELLENBERG H. Aims and Methods of Vegetation Ecology. The Blackburn Press, 547, 2002.

33. MATUSZKIEWICZ J.M. Forest communities of Poland. Wydawnictwo Naukowe PWN, Warszawa; 2007.

34. JADCZYK P. Causes of degradation of forests in the Izerskie and Karkonosze Mountains. I. Environmental conditions and anthropogenic factors. Sylwan 12, 39, 1994.

35. JADCZYK P. Natural effects of large area forest decline in West Sudety Mountains. Environment Protection Engineering 35 (1), 49, 2009.

36. ZERBE S. Restoration of natural broad-leaved woodland in Central Europe on sites with coniferous forest plantations. Forest. Ecol. Manag. 167 (1-3), 27, 2002.

37. NOCENTINI S. Structure and management of beech (Fagus sylvatica L.) forests in Italy. iForest 2, 105, 2009.

38. DUBRAVAC T., DEKANIĆ S., NOVOTNY V., MILAŠINČIĆ J. Natural Regeneration of Beech Forests in the Strict Protected Area of the Plitvice Lakes National Park. South-East Europ. Forestry 4 (2), 95, 2013.

39. COATES K.D., BURTON P.J. A gap-based approach for development of silvicultural systems to address ecosystem management objectives. Forest. Ecol. Manag. 99 (3), 337, 1997.
40. MATTHES U., AMMER U. Conversion of Norway Spruce (Picea abies L.) Stands into Mixed Stands with Norway Spruce and Beech (Fagus sylvatica L.) - Effects on the Stand Structure in Two Different Test Areas. In: Klimo E, Hager H, Kulhavý J (eds), Spruce Monocultures in Central Europe Problems and Prospects. EFI Proceedings 33, 71, 2000.

41. BARNA M. The effects of cutting regimes on natural regeneration in submountain beech forests: species diversity and abundance. Journal of Forest Science 54 (12), 533, 2008.

42. CHRISTENSEN M., HAHN K., MOUNTFORD E.P., ÓDOR P., STANDOVÁR T., ROZENBERGARD D., DIACI J., WIJDEVEN P., METERS P., WINTER S., VRSKA T. Dead wood in European beech (Fagus sylvatica) forest reserves. Forest. Ecol. Manag. 210 (1-3), 267, 2005.

43. BRUNET J., FRITZ Ö., RICHNAU G. Biodiversity in European beech forests - a review with recommendations for sustainable forest management. Ecol. Bull. 53, 77, 2010.

44. SEIDLING W., TRAVAGLINI D., MEYER P., WALDNER P., FISCHER R., GRANKE O., CHIRICI G., CORONA P. Dead wood and stand structure - relationships for forest plots across Europe. iForest 7, 269, 2014.

45. VANDEKERKHOVE K., KEERSMAEKER L., BAETÉ H., WALLEYN R. Spontaneous re-establishment of natural structure and related biodiversity in a previously managed beech forest in Belgium after 20 years of non intervention. Forest Snow and Landscape Research 79 (1/2), 145, 2005.

46. VANDEKERKHOVE K., DE KEERSMAEKER L., MENKE N., MEYER P., VERSCHELDE P. When nature takes over from man: Dead wood accumulation in previously managed oak and beech woodlands in North-western and Central Europe. Forest. Ecol. Manag. 258 (4), 425, 2009.

47. INSTITUTE OF NATURE CONSERVATION POLISH ACADEMY OF SCIENCES Monitoring gatunków i siedlisk przyrodniczych. http://www.iop.krakow.pl/cn2000/ Monitoring/Default.aspx, 2015.

48. ZEHETMAIR T., MÜLLER J., ZHAROV A., GRUPPE A. Effects of Natura 2000 and habitat variables used for habitat assessment on beetle assemblages in European beech forests. Insect Conserv. Diver. online doi:10.1111/icad.12101. 2014.

49. ZEHETMAIR T., MÜLLER J., RUNKEL V., STAHLSCHMIDT P., WINTER S., ZHAROV A., GRUPPE A. Poor effectiveness of Natura 2000 beech forests in protecting forest-dwelling bats. J. Nat. Conserv. 23, 53, 2015.

50. MÖLDER A., STREIT M., SCHMIDT W. When beech strikes back: How strict nature conservation reduces herblayer diversity and productivity in Central European deciduous forests. Forest. Ecol. Manag. 319, 51, 2014.

51. WINTER S., BORRASS L., GEITZENAUER M., BLONDET M., BREIBECK R., WEISS G., WINKEL G. The impact of Natura 2000 on forest management: a socioecological analysis in the continental region of the European Union. Biodivers. Conserv. 23 (14), 3451, 2014. 
